\title{
Comparison of mould filament counting techniques for industrialized tomato sauces
}

\author{
Comparação de técnicas para contagem de fungos filamentosos em molhos \\ de tomate industrializados
}

\author{
Regina Célia Arantes Stancari', Larissa Fiamengui de Pauli², Gabriel Antonio Nogueira Nascentes², \\ Laís Anversa ${ }^{1 *}$ (iD \\ 1 Instituto Adolfo Lutz (IAL), Centro de Laboratório Regional de Bauru, Núcleo de Ciências Químicas e Bromatológicas, Bauru/SP - Brasil \\ 2 Instituto Adolfo Lutz (IAL), Centro de Laboratório Regional de Bauru, Núcleo de Ciências Químicas e Bromatológicas, Programa de Aprimoramento \\ Profissional (FUNDAP - SES/SP), Bauru/SP - Brasil \\ ${ }^{3}$ Instituto Federal de Educação, Ciência e Tecnologia do Triângulo Mineiro (IFTM), Uberaba/MG - Brasil
}

\section{${ }^{*}$ Corresponding Author}

Laís Anversa, Instituto Adolfo Lutz (IAL), Centro de Laboratório Regional de Bauru, Núcleo de Ciências Químicas e Bromatológicas, Rua Rubens Arruda, Quadra 6, Centro, CEP: 17015-110, Bauru/SP - Brasil, e-mail: laisanversa@yahoo.com.br

Cite as: Comparison of mould filament counting techniques for industrialized tomato sauces. Braz. J. Food Technol., v. 21, e2017234, 2018.

Received: Oct. 17, 2017; Accepted: Feb. 27, 2018

\section{Abstract}

The objective of this study was to compare different techniques for counting mould filaments in industrialized tomato sauces available on the Brazilian market. In order to do so, 42 samples of the product "traditional tomato sauce" (from 21 different brands), sold in supermarkets in the municipality of the city of Bauru, Brazil, were collected during the period from April to June, 2016. The mycelial moulds were counted by the Howard method according to the official methodology recommended by the Association of Official Analytical Chemists (AOAC), applying techniques 965.41 and 945.92. Notably, the application of technique 945.92 using sodium hydroxide $(\mathrm{NaOH})$ to eliminate the starch in the samples, facilitated counting of the hyphae and, consequently, the percentages of positive fields observed were significantly higher $($ median $=10 \%)$ when compared with the percentages obtained after using technique 965.41 (median $=6 \%)(p<0.001)$. The present findings reveal the need to expand the discussion concerning the application of different techniques for the counting of mould filaments in industrialized tomato sauces, especially in Brazil and in other countries that do not prohibit the addition of starch to this kind of product.

Keywords: Tomato; Tomato sauce; Howard method; Mould filaments; Microscopic analysis; Contamination.

\section{Resumo}

O objetivo do presente estudo foi comparar diferentes técnicas para a contagem de fungos filamentosos em molhos de tomate industrializados, comercializados no Brasil. Para isso, foram colhidas 42 amostras do produto do tipo "molho de tomate tradicional", de 21 marcas diferentes, comercializadas em supermercados do município de Bauru-SP, no período de abril a junho de 2016. A contagem de filamentos micelianos pelo método de Howard foi realizada segundo a metodologia oficial, recomendada pela Association of Official Analytical Chemists (AOAC), aplicando-se as técnicas 965.41 e 945.92. Notadamente, a aplicação da técnica 945.92, que utiliza hidróxido de sódio ( $\mathrm{NaOH}$ ) para eliminar o amido presente nas amostras, facilitou a contagem das hifas e, consequentemente, as porcentagens de campos positivos observadas foram significativamente maiores (mediana $=10 \%$ ), quando comparadas com as porcentagens obtidas após a utilização da técnica 965.41 (mediana $=6 \%)(p<0,001)$. Nossos achados apontam a necessidade de se ampliar a discussão sobre a aplicação de diferentes técnicas para a contagem de fungos filamentosos em molhos de tomate industrializados, especialmente no Brasil e em outros países que não proíbem a adição de amido nesse tipo de produto.

Palavras-chave: Tomate; Molho de tomate; Método de Howard; Fungos filamentosos; Análises microscópicas; Contaminação. 


\section{Introduction}

Originating in the occidental part of the Central and South Americas, from where it was taken to other continents, the tomato (Lycopersicum sp.) is an important vegetable on the global scenario, that rates together with other products highly widespread throughout the world, such as potatoes, onions and garlic (CAMARGO; CAMARGO FILHO, 2008). According to the World Health Organization for Food and Agriculture (FAO), Brazil rates in 8th place in the global production ranking of tomato, producing around four million tons per year (IBGE, 2015).

Along with the in natura form, tomatoes are also widely consumed in industrialized products such as purees, pulps, juices, jams, ketchup, and especially sauces (SOARES; RANGEL, 2012), the latter being increasingly inserted in the daily diet of the population, due to the increase in demand for ready-to-eat food.

According to Brazilian legislation, "sauces" are generally defined as products in the form of liquids, pastes, emulsions or suspensions, including spices, seasonings and/or other ingredients, fermented or not, that can be used to prepare and add flavour to food (BRASIL, 2005). However, inevitably, the industrialized tomatoes that are used in the preparation of these products are exposed to physical, chemical and microbiological contamination during all the production processes, fungal contamination being the major agent responsible for the decrease in productivity and quality of these tomatoes and their derivatives (CPT, 2010).

Despite the fact that most of the fungi are destroyed during the thermal phase of the manufacturing process, the presence of hyphae (cell filaments that form the fungal mycelium) in the final product indicates that the raw material was contaminated with these organisms or that flaws occurred during the application of the good manufacturing practices whilst processing (ATUI et al., 2012).

In 1910, B. J. Howard described a method for counting mould filaments known as the "Howard method". This author demonstrated there was a relationship between the hyphal count in the final product and the percent in weight of rotten fruit present in the raw material (ATUI et al., 2012). Thus in practice, the Howard mould filament count is an important indicator of the quality of the raw material that was used (TANIWAKI et al., 2011; LATIMER JUNIOR, 2016).

In Brazil, industrialized products derived from tomatoes must attend, amongst other legislation, the directives of Resolution RDC 14/14/ANVISA/MS concerning the presence and tolerance limits of extraneous matter in food and drinks (BRASIL, 2014). According to this legislation, the Howard mycelial mould count applied to tomato sauces should not show values above $40 \%$ of positive fields, and should be carried out according to technique 965.41 as recommended by the Association of Official Analytical Chemists (AOAC). In the cases of the tomato sauces present in pork and beans, spaghetti, ravioli, chili, tamales and others, the maximum value allowed is $12 \%$ of positive fields and the analysis must be carried out by applying technique 945.92, also recommended by the AOAC.

However, the industrialized tomato sauces available in Brazilian supermarkets nowadays frequently contain starch in their composition, which makes the application of the 965.41 technique difficult. Thus considering the above, the objective of this study was to compare different techniques (Tech. 965.41 and Tech. 945.92) for counting the mould filaments in industrialized tomato sauces commercialized in Brazil.

\section{Material and methods}

Samples of industrialized tomato sauce were bought in supermarkets located in the city of Bauru, Brazil, during April and June, 2016. Two samples were collected from two different batches from each of 21 different brands of the product (total of 42 samples) of the type "traditional tomato sauce", sold in airtight packaging and stable to room temperature, within the shelf life of the product and showing no visible signs of violations or alterations.

After collection, the samples were sent at room temperature to the Chemical and Bromatological Centre of the Adolfo Lutz Institute, Regional Laboratory Centre of Bauru (IAL - CLR Bauru), where the analyses were carried out.

The Howard mycelial mould count was carried out according to the recommendations of the Association of Official Analytical Chemists (LATIMER JUNIOR, 2016), applying techniques 965.41 and 945.92, the second of which differs from the first by including treatment with a $1+1$ sodium hydroxide $(\mathrm{NaOH})$ solution.

\section{Description:}

AOAC Official Method 965.41: Moulds in Tomato Products

Applicable to tomato juice, sauce, ketchup, paste and puree.

In making mould counts of tomato products, use the juice and sauce as they come from the container. Proceed as in 984.29.

AOAC Official Method 945.92: Moulds in Tomato Sauce

Applicable to the sauce in pork and beans, spaghetti, ravioli, chili con carne, tamales, etc.

Place the unopened, punctured can in hot water and heat until the contents are thoroughly warmed. Open the can and transfer the contents to a No. 6 sieve. Drain until 
the majority of the liquid has passed through. Mix the sauce thoroughly, place $10 \mathrm{~mL}$ in a centrifuge tube, and add $3 \mathrm{~mL} \mathrm{NaOH}$ solution (1+1). Stir until the starch has dissolved and the tissues are clear. Add enough $\mathrm{H}_{2} \mathrm{O}$ to fill the tube and centrifuge. The time required to centrifuge the mixture varies greatly. With a centrifuge arm length of $5 \frac{1}{4} \mathrm{in}$. $(13.3 \mathrm{~cm}$ ) and speed of ca $1600 \mathrm{rpm}$, ca $20 \mathrm{~min}$ is required for the average product. When the supernatant is clear, pour it off, but if is not entirely clear, check the supernatant for mould before discarding. Add enough $\mathrm{H}_{2} \mathrm{O}$ to the residue in the tube to come to volume, mix, and make the mould count as in 984.29.

\section{AOAC Official Method 984.29: Howard Mould Count}

Clean the Howard cell so that Newton's rings are produced between the slide and the coverslip. Remove the coverslip and with a knife blade or scalpel, place a portion of well-mixed test sample on the central disk, spread it evenly over the disk with the same instrument, and cover with the coverslip so as to give a uniform distribution. Use only enough test material to reach the edge of the disk. Discard any mount showing an uneven distribution or the absence of Newton's rings, or one where the liquid has crossed the dip between the coverslip and the shoulder.

Place the slide under the microscope and examine with a suitable adjustment such that each field of view covers $1.5 \mathrm{sq}$. mm. Use a magnification of $x 90-125$. If the characteristics of the mould filaments are not clearly discernible in the standard field, use a magnification of ca $\times 200$ (8 $\mathrm{mm}$ objective) to confirm the identity of the mould filaments previously observed in the standard field.

From each of two mounts, examine 25 fields taken in such a manner as to be representative of all the sections of the mount.

A field is scored either positive or negative. No field can be scored positive more than once. The method requires that the field be counted as positive when the aggregated lengths of not $>3$ mould filaments exceed $1 / 6$ of the diameter of the field. Exactly one-sixth of the diameter of the field is not enough to be counted as positive - the aggregated length must exceed 1/6 of the diameter of the field.

Calculate the proportion of positive fields from the results of the examination of all the observed fields and report as \% positive fields.

The statistical analysis of the results was carried out employing the Wilcoxon Test (paired samples), considering a difference to be significant when $p<0.05$.

\section{Results and discussion}

The analysis of the extraneous matter is important for both the selection of the raw material for food manufacturing and in monitoring the quality of processed foods. The presence of extraneous matter in food products is unpleasant and can cause serious health hazards to the consumer. The main reason for carrying out analyses for extraneous matter in food is to ensure the protection of consumers from harmful or filthy food products (TILOCCA et al., 2015).

Notably, there is still little work available in the world literature concerning the analyses of products derived from tomato. However, tomato fruits are exposed to several physical and biological contaminants, especially when they suffer injury and damage to their tissues (AL-HINDI et al., 2011).

Fungal contamination is frequently the major cause of reductions in the yield and in the quality of the tomato fruit and its derivatives (CPT, 2010). The main fungi that affect these products include Alternaria, Aspergillus, Botrytis, Cladosporium, Fusarium, Geotrichum, Penicillium, Phytophthora, Rhizopus and Stemphylium (REIS; LOPES, 2012; DOAN et al., 2016; MAILAFIA et al., 2017).

Table 1 shows, in detail, the results of the Howard mould filament count in the samples of tomato sauce analysed, applying the two techniques cited above.

In general, $97.6 \%$ of the samples investigated presented mycelial moulds, detected using at least one of the techniques employed. Despite the fact that current

Table 1. Results of the Howard mould filament count in industrialized tomato sauces applying two distinct techniques.

\begin{tabular}{|c|c|c|c|c|}
\hline \multirow{3}{*}{ BRAND } & \multicolumn{4}{|c|}{ Percentage $(\%)$ of positive fields } \\
\hline & \multicolumn{2}{|c|}{$1^{\text {st }}$ sample } & \multicolumn{2}{|c|}{$2^{\text {nd }}$ sample } \\
\hline & $\begin{array}{c}\text { Tech. } \\
965.41\end{array}$ & $\begin{array}{c}\text { Tech. } \\
945.92\end{array}$ & $\begin{array}{c}\text { Tech. } \\
965.41\end{array}$ & $\begin{array}{c}\text { Tech. } \\
945.92\end{array}$ \\
\hline A & 6 & 8 & 20 & 24 \\
\hline B & 49 & 82 & 52 & 74 \\
\hline C & 4 & $\left({ }^{*}\right)$ & 3 & 10 \\
\hline D & 6 & 10 & 12 & 10 \\
\hline $\mathbf{E}$ & 10 & 11 & 21 & 34 \\
\hline $\mathbf{F}$ & 2 & 4 & 4 & 10 \\
\hline $\mathbf{G}$ & 4 & 8 & 8 & 10 \\
\hline $\mathbf{H}$ & 0 & 3 & 10 & 8 \\
\hline $\mathbf{I}$ & 4 & 8 & 6 & 10 \\
\hline $\mathbf{J}$ & 2 & 4 & 7 & 12 \\
\hline$K$ & 4 & 2 & 6 & 8 \\
\hline $\mathbf{L}$ & 25 & 55 & 17 & 18 \\
\hline M & 0 & 2 & 0 & 0 \\
\hline $\mathbf{N}$ & 3 & 4 & 6 & 6 \\
\hline 0 & 2 & 8 & 6 & 6 \\
\hline $\mathbf{P}$ & 78 & 98 & 77 & 99 \\
\hline $\mathbf{Q}$ & 2 & 8 & 0 & 6 \\
\hline $\mathbf{R}$ & 6 & 12 & 6 & 14 \\
\hline$S$ & 8 & 9 & 0 & 8 \\
\hline $\mathbf{T}$ & 100 & 100 & 3 & 35 \\
\hline $\mathbf{U}$ & 6 & 12 & 2 & 4 \\
\hline
\end{tabular}

$\left(^{*}\right)$ Analysis not carried out. 
legislation does not consider the presence of mould filaments in foods as harmful to human health, their presence certainly indicates the use of decayed raw material (BRASIL, 2014).

Corroborating with these findings, high filamentous fungal counts have also been described in sweet fruit preserves, especially those made from guava fruit, with $100 \%$ of the samples presenting mycelial filaments (minimum 9\% and maximum 96\% positive fields) (CORREIA; RONCADA, 2002).

Comparing the results obtained by the different techniques, $90.5 \%$ of the tomato sauces analysed presented higher percentages of mycelial moulds when using technique 945.92, where sodium hydroxide $(\mathrm{NaOH})$, was employed.

The analyses of the first samples showed median values of $4 \%$ and $8 \%$, applying techniques 965.41 and 945.92, respectively, while the analyses of the second sample showed median values of $6 \%$ and $10 \%$, respectively (Figure 1)

In general, the median observed using the 945.92 technique was $10 \%$ of positive fields, which was significantly higher when compared to the median found after application of the 965.41 technique, which was $6 \%$ of positive fields ( $p<0.001)$ (Figure 2).

The $\mathrm{NaOH}$ solution is commonly used in microscopic techniques in order to promote acid hydrolysis of the starch contained in the samples, transforming it into glucose, which allows a better visualization of the histological elements during the microscopic examination.

Brazilian law does not forbid the addition of starch to industrialized tomato sauces, and currently different concentrations are added by the industries. In the present study, the use of Technique 945.92 favoured the analytical phase of sample reading, seen as critical and difficult to carry out, demanding trained and highly prepared professionals. The treatment of the samples with $\mathrm{NaOH}$ eliminated the starch added to the products and hence the hyphae of the mould filaments were more clearly visible, making it easier to count the positive fields in the samples under analysis.

Although this was not the focus of this research, it is also worth noting that, , according to current legislation, using technique 965.41, 5 (11.9\%) samples presented unsatisfactory results ( $>40 \%$ of positive fields), whereas applying technique 945.92, 6 (14.3\%) samples would be disapproved.

As previously reported, although most fungi are inactivated during the heat processing stage of industrialization, the use of damaged tomatoes and fungi in the preparation of tomato sauces may represent a health risk to the consumer, since the occurrence of heat resistant fungi may deteriorate the product (SALOMÃO et al., 2008), and the presence of mycotoxins, which are toxic secondary metabolites,

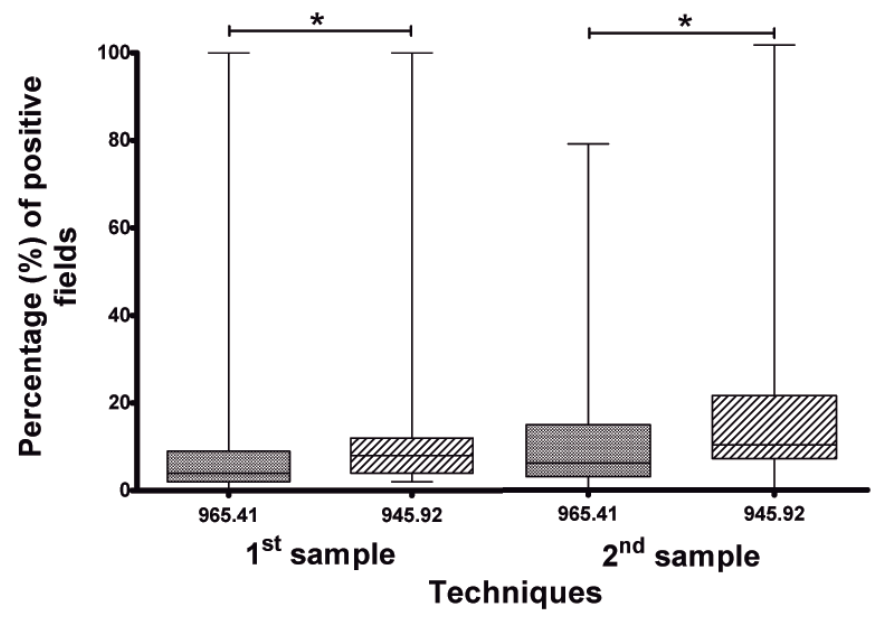

Figure 1. Comparative analysis (median and amplitude) of the results obtained for the Howard mould filament count in industrialized tomato sauces applying two distinct techniques - per sample. ${ }^{*} p<0.001$ (Wilcoxon Test).

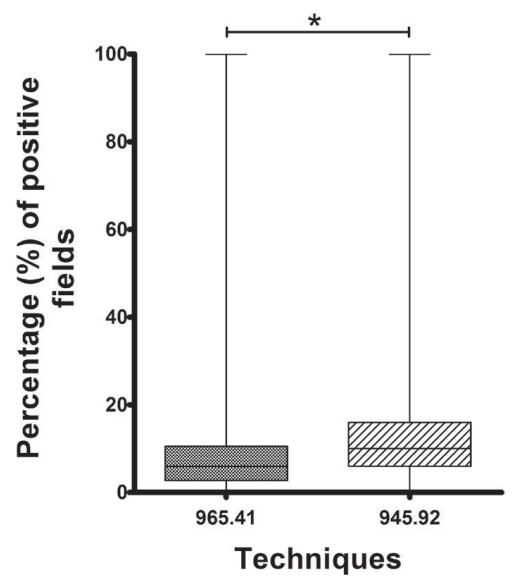

Figure 2. Comparative analysis (median and amplitude) of the results obtained for the Howard mould filament count in industrialized tomato sauces applying two distinct techniques - in general. ${ }^{*} p<0.001$ (Wilcoxon Test).

may cause pathological damage due to the possible hepatotoxic, mutagenic, teratogenic and carcinogenic properties (MURPHY et al., 2006; SANTOS, 2014). In fact, several mycotoxins have been reported in various tomato products produced and marketed in Argentina, Switzerland and Germany (VAN DE PERRE et al., 2013). In Brazil, da Motta and Soares (2001) analysed 80 samples of tomato products, including juices, pulps, extracts and sauces, and found mycotoxins in $20 \%$ of the samples analysed. More recently, also in Brazil, Santos (2014) found mycotoxins from Alternaria alternata in ketchup samples.

Differently from the present findings, when investigating the hygienic conditions of foods included in the "basic baskets" marketed in the State of São Paulo, Daros et al. (2010) analysed tomato purée samples using 
technique 965.41, and did not observe mycelial mould counts above $40 \%$. In the same fashion, Santos et al. (2015) evaluated tomato products (purée, pulp, ketchup) from three different brands obtained in the Federal District and all were adequate with respect to the mould filament count.

Finally this work represents an unpublished study comparing techniques for counting mould filaments in industrialized tomato sauces, and the results show that the application of technique 945.92 may favour the counting of hyphae, especially in cases of tomato sauces that contain starch. Thus further studies are necessary in order to standardize possible applications of the different techniques to carry out the Howard methodology in these products. Furthermore, taking into account that the presence of mycelial moulds in tomato products is attributed to the fruit itself, it is necessary to study the influence of the addition/concentration of starch on the indication of positive fields by the Howard method, and hence the maximum tolerated limit, as defined by Resolution RDC 14/14/ANVISA/MS (Brasil, 2014).

\section{Conclusion}

The use of technique 945.92 for counting mould filaments in industrialized tomato sauces seems to facilitate counting of the hyphae, proving to be adequate especially in the cases of tomato sauces containing starch. Further studies are necessary in order to broaden the discussion on the application of different techniques to the industrialized tomato sauces commercialized in Brazil and in other countries that do not prohibit the addition of starch to this type of product. In addition, the presence of mould filaments in industrialized tomato sauces shows the need to improve good manufacturing practices, improving the quality of the raw material and the hygienic and sanitary conditions employed in the productive chain, in order to increase the safety and quality of the products, and thus protect the health of the population.

\section{References}

AL-HINDI, R. R.; AL-NAJADA, A. R.; MOHAMED, S. A. Isolation and identification of some fruit spoilage fungi: screening of plant cell wall degrading enzymes. African Journal of Microbiological Research, v. 5, n. 4, p. 443-448, 2011.

ATUI, M. B.; NOGUEIRA, M. D.; SILVA, A. M.; MARCINAO, M. A. M.; FIORAVANTI, M. I. A.; CHASIN, L. B.; FRANCO, V. P. A.; SILVA, L. A.; OLIVEIRA, M. M. L.; CARDOSO-GUSTASON, P.; HAYASHI, A. H. Manual de análise microscópica em polpas de frutas: açai (Euterpe oleracea), goiaba (Psidium guajava), manga (Mangifera sp), morango (Fragaria vesca), tomate (Lycopersicum sp). São Paulo: Instituto Adolfo Lutz, 2012. cap. 3. 72 p.

BRASIL. Agência Nacional de Vigilância Sanitária - ANVISA. Resolução RDC n² 276, de 22 de setembro de 2005. Aprova o Regulamento técnico para especiarias, temperos e molhos.
Diário Oficial [da] República Federativa do Brasil, Brasília, DF, 23 set. 2005.

BRASIL. Agência Nacional de Vigilância Sanitária - ANVISA. Resolução RDC n 14, de 28 de março de 2014. Dispõe sobre matérias estranhas macroscópicas e microscópicas em alimentos e bebidas, seus limites de tolerância e dá outras providências. Diário Oficial [da] República Federativa do Brasil, Brasília, DF, 31 jan. 2014.

CAMARGO, F. P.; CAMARGO FILHO, W. P. Produção de tomate de mesa no Brasil, 1990-2006: contribuição da área e da produtividade. Horticultura Brasileira, v. 26, n. 2, p. S1018S1021, 2008

CENTRO DE PRODUÇÕES TÉCNICAS - CPT. Tomate industrial: o Brasil está entre os dez maiores produtores da hortaliça no mundo. Viçosa, 2010. Available at: <http://www.cpt.com.br/artigos/ tomate-industrial-o-brasil-esta-entre-os-dez-maioresprodutoresda-hortalica-no-mundo>. Accessed on: 20 sept. 2016.

CORREIA, M.; RONCADA, M. J. Padronização de método e quantificação de matérias estranhas e filamentos micelianos. Revista do Instituto Adolfo Lutz, v. 61, n. 2, p. 85-90, 2002.

DAROS, V. S. M. G.; PRADO, S. P. T.; MARTINI, M. H. Alimentos embalados que compõem as cestas básicas: avaliação microscópica e da rotulagem. Revista do Instituto Adolfo Lutz, v. 69, p. 525-530, 2010.

DOAN, H. K.; PEREZ, K.; DAVIS, R. M.; SLAUGHTER, D. C. Survey of molds in California processing tomatoes. Journal of Food Science, v. 81, n. 11, p. M2785-M2792, 2016. http://dx. doi. org/10.1111/1750-3841.13525. PMid:27711969.

INSTITUTO BRASILEIRO DE GEOGRAFIA E ESTATÍSTICA IBGE. Levantamento sistemático da produção agrícola. Rio de Janeiro, 2015. Available at: <http://www.ibge.gov.br/home/ estatistica/indicadores/agropecuaria/lspa>. Accessed on: 29 sept. 2016

LATIMER JUNIOR, G. W. (Ed.). Official methods of analysis of AOAC International. 20th ed. Gaithersburg: AOAC, 2016.

MAILAFIA, S.; OKOH, G. R.; OLABODE, H. O. K.; OSANUPIN, $R$. Isolation and identification of fungi associated with spoilt fruits vended in Gwagwalada market, Abuja, Nigeria. Veterinary World, v. 10, n. 4, p. 393-397, 2017. http://dx.doi.org/10.14202/ vetworld.2017.393-397. PMid:28507410.

MOTTA, S.; SOARES, L. M. V. Survey of Brazilian tomato products for alternariol, alternariol monomethyl ether, tenuazonic acid and cyclopiazonic acid. Food Additives and Contaminants, v. 18, n. 7, p. 630-634, 2001. http://dx.doi.org/10.1080/02652030117707. PMid:11469319.

MURPHY, P. A.; HENDRICH, S.; LANDGREN, C.; BRYANT, C. M. Food mycotoxins: an update. Journal of Food Science, v. 71, n. 5, p. R51-R65, 2006. http://dx.doi.org/10.1111/j.17503841.2006.00052.x 
Comparison of mould filament counting techniques for industrialized tomato sauces

Stancari, R. C. A. et al.

REIS, A.; LOPES, C. A. Doenças causadas por fungos e distúrbios fisiológicos. In: CLEMENTE, F. M. V. T.; BOITEUX, L. S. Produção de tomate para processamento industrial. Brasília: Embrapa, 2012. p. 179-202.

SALOMÃO, B. C. M.; MASSAGUER, P. R.; ARAGÃO, G. M. F. Isolamento e seleção de fungos filamentosos termorresistentes em etapas do processo produtivo de néctar de maçã. Food Science and Technology, v. 28, n. 1, p. 116-121, 2008. http:// dx.doi.org/10.1590/S0101-20612008000100017.

SANTOS, G. G. Qualidade físico-química, microbiológica e ocorrência de micotoxinas de Alternaria alternata em derivados de tomate. 2014. 92 f. Tese (Doutorado)-Programa de Pós-graduação em Nutrição Humana, Departamento de Nutrição, Faculdade de Ciências da Saúde, Universidade de Brasília, Brasília, 2014.

SANTOS, G. G.; MATTOS, L. M.; MORETTI, C. L. Qualidade microbiológica e presença de resíduos microscópicos em derivados de tomate. In: SIMPÓSIO DE SEGURANÇA ALIMENTAR, 5., 2015, Bento Gonçalves. Anais... Porto Alegre: SBCTA, 2015.
SOARES, B. B.; RANGEL, R. Aspectos industriais da cultura. In: CLEMENTE, F. M. V. T.; BOITEUX, L. S. Produção de tomate para processamento industrial. Brasília: Embrapa, 2012. p. 331-344.

TANIWAKI, M. H.; IAMANAKA, B. T.; SILVA, N. Fungos deterioradores de alimentos: ocorrências e detecção. Campinas: Instituto de Tecnologia de Alimentos, 2011. 65 p.

TILOCCA, M. G.; CANEGLIAS, E.; VODRET, B.; MANCUSO, M. R.; ZIMMARDI, A.; MANNO, C.; SCHIAVO, M. R. Analysis of foreign matter in foodstuffs using the light filth test: report 2012-2013. Italian Journal of Food Safety, v. 4, n. 3, p. 4504, 2015. PMid:27800401.

VAN DE PERRE, E.; DESCHUYFFELEER, N.; JACXSENS, L.; VEKEMAN, F.; VAN DER HAUWAERT, W.; ASAM, S.; RYCHLIK, M.; DEVLIEGHERE, F.; DE MEULENAER, B. Screening of moulds and mycotoxins in tomatoes, bell peppers, onions, soft red fruits and derived tomato products. Food Control, v. 37, p. 165-170, 2013. http://dx.doi.org/10.1016/j.foodcont.2013.09.034. 